\title{
MENULIS PENGALAMAN EMOSIONAL UNTUK MENURUNKAN DEPRESI PADA PEREMPUAN KORBAN KEKERASAN
}

\section{WRITING EMOTIONAL EXPERIENCE TO DECREASE DEPRESSION ON WOMEN AS VICTIMS OF VIOLENCE}

\author{
Vequentina Puspa Indah \\ Fakultas Psikologi dan IImu Sosial Budaya Universitas Islam Indonesia, Yogyakarta \\ e-mail: vequentina@yahoo.com
}

\section{Tina Afiatin}

Fakultas Psikologi Universitas Gadjah Mada, Yogyakarta

\section{Yulianti Dwi Astuti}

Fakultas Psikologi dan IImu Sosial Budaya Universitas Islam Indonesia, Yogyakarta

\begin{abstract}
The study was based on a hypothesized statement that writing emotional experience were influenced to decrease depression on women as victims of violence. The participants of the study consisted of 14 women victims of violence, and classified into two groups. One group went through a procedure of writing an emotional experience, the other served as a controlled group. Beck Depression Inventory was completed by each participants to measure the level depression. The pretest was given before writing an emotional experience. The posttest was given immediately after the procedure, and follow-up was given two weeks after posttest. The hypothesis analyzed using Wilcoxon's and Mann Whitney test for nonparametric statistics. The result of the study found that the participants who wote emotional experience shown a significant decrease of depression right after the procedure, but it did not last until two weeks after the procedure. The conclusion was writing that emotional experience an be used as a one of the form of therapy to decrease the level of depression on women as victims of violence.
\end{abstract}

Keyword: writing emotional experience, depression, women victims of violence 


\begin{abstract}
ABSTRAK
Penelitian dilakukan dengan tujuan untuk mengetahui pengaruh menulis pengalaman emosional dalam menurunkan depresi pada perempuan korban kekerasan. Hipotesis yang diajukan adalah ada perbedaan tingkat depresi pada perempuan korban kekerasan yang melakukan prosedur menulis pengalaman emosional dan perempuan korban kekerasan yang tidak melakukan prosedur menulis pengalaman emosional. Subjek penelitian terdiri atas 14 orang perempuan korban kekerasan yang dibagi ke dalam kelompok kontrol dan kelompok eksperimen. Prosedur menulis pengalaman emosional dilakukan dalam 4 sesi. Pengukuran dilakukan dengan menggunakan Beck Depression Inventory (BDI). Pengukuran tingkat depresi dilakukan sebelum pelaksanaan prosedur menulis pengalaman emosional, setelah pelaksanaan prosedur, dan dua minggu setelah pelaksanaan prosedur. Hipotesis diuji dengan teknik Wilcoxon dan Mann Whitney. Hasil penelitian menunjukkan penurunan tingkat depresi pada perempuan korban kekerasan terjadi setelah dilakukannya prosedur menulis pengalaman emosional, namun tidak efektif lagi pada jangka waktu dua minggu setelahnya. Dengan demikian prosedur ini dapat digunakan sebagai awalan atau pembuka bagi serangkaian intervensi lainnya yang ditujukan untuk menurunkan depresi pada perempuan korban kekerasan.
\end{abstract}

Kata kunci: menulis pengalaman emosional, depresi, perempuan korban kekerasan

Kekerasan merupakan suatu tindakan yang berujung pada adanya pelanggaran hak asasi manusia, atau secara lebih khusus berujung pada pelanggaran yang menghalangi manusia untuk memenuhi kebutuhan dasarnya, seperti pemenuhan rasa aman. Meskipun semua orang pernah mengalami kekerasan, namun kasus kekerasan lebih banyak menimpa perempuan. Hal ini seperti yang telah dinyatakan oleh Unger dan Crawford (Uyun, 2004) bahwa terdapat banyak kasus kekerasan dengan perempuan sebagai korban dan laki-laki sebagai penyerang. Ditambah lagi, Mandatu (2009) yang memperkuat pernyataan tersebut dengan menunjukkan persentase
95\% korban kekerasan berbasis gender adalah perempuan.

Di Indonesia, kasus kekerasan terhadap perempuan tercatat semakin meningkat tiap tahunnya. Sub Komisi Pemantauan Komnas Perempuan menyatakan bahwa kekerasan terhadap perempuan mengalami peningkatan dari tahun 2008 ke 2009 hingga Januari 2010 dengan peningkatan hampir 3 kali lipat. Angka kekerasan terhadap perempuan ini tertinggi terjadi di Jawa Timur dengan jumlah 88.836 korban, menyusul DKI Jakarta dengan jumlah 12.955 korban, dan Daerah Istimewa Yogyakarta (DIY) 10.560 korban (www.detiknews.com, 8/1/2012). 
Terlepas dari berbagai penyebab yang melatarbelakanginya, kekerasan terhadap perempuan akan mengakibatkan dampak yang beragam bagi korbannya mulai dari dampak secara fisik maupun secara psikologis. Penelitian Darmawan (2005) menemukan fakta bahwa semua jenis kekerasan akan memiliki implikasi psikologis. Hal itu terjadi karena kekerasan psikologis merupakan efek domino dari jenis dan bentuk kekerasan lainnya. Zubaidah (2001) menyebutkan bahwa dampak fisik yang terjadi dapat berupa luka memar, bengkak berdarah, gegar otak, pingsan, luka bakar hingga luka yang berkaitan dengan fungsi seksual dan reproduksi. Sedangkan dampak psikologis yang sering terjadi pada perempuan korban kekerasan adalah perasaan tidak percaya diri, kecemasan, gangguan emosi, stres, merasa tidak berharga, rendah diri, menutup diri serta depresi. Sementara itu, Wardhani dan Lestari (2007) menyebutkan bahwa banyak perempuan korban kekerasan yang kemudian mengalami depresi dan menjadi tidak tertarik untuk melakukan hal-hal yang sebelumnya diminatinya. Mereka mengembangkan perasaan bersalah dan terus menyalahkan diri sendiri atas peristiwa yang terjadi, bahkan kerap mengembangkan pikiran-pikiran untuk bunuh diri.

Dari pengalaman peneliti sebagai pendamping bagi perempuan korban kekerasan di sebuah panti sosial milik Dinas Sosial Provinsi DIY, yaitu PSKW
(Panti Sosial Karya Wanita) Sidoarum, ditemukan berbagai kasus di mana perempuan korban kekerasan lebih sering mengalami penurunan motivasi dalam mengikuti pendidikan di panti. Perempuan korban kekerasan ini mudah sekali menyerah atau merasa tidak mampu untuk menyelesaikan persoalan kehidupan sehari-hari yang dialami. Mereka juga cenderung membutuhkan dukungan sosial lebih banyak dibandingkan dengan penghuni panti yang tidak memiliki riwayat sebagai korban kekerasan. Selain itu korban kerap merasa tidak memiliki harapan masa depan, kurang percaya diri dalam pergaulan di panti, mudah putus asa menghadapi persoalan hidup, menarik diri dari lingkungan serta merasa tidak berharga. Hal ini menunjukkan bahwa perempuan korban kekerasan mengalami simtom-simtom depresi. Pada akhirnya hal ini menghambat program pemulihan yang dilakukan terhadap korban di panti sosial tersebut.

Depresi sering kali disebut sebagai gangguan mood atau gangguan suasana perasaan karena terdapat kondisi emosi negatif yang kompleks seperti kesedihan, kecemasan, kemarahan dan rasa bersalah. Beck (1985) menyebutkan bahwa penderita depresi akan menunjukkan simtom emosional, simtom motivasional, simtom kognitif, simtom perilaku, dan simtom vegetatif. Simtom emosional menunjuk pada suasana mood yang berubah, seperti kesedihan, kesepian dan pesimis. Simtom motivasional menunjuk 
pada perubahan tingkat aktivitas, seperti malas atau gelisah. Simtom kognitif menunjuk pada konsep diri yang negatif yang dihubungkan dengan rasa bersalah dan rendah diri. Simtom perilaku menunjuk pada pengunduran diri dari hubungan sosial dan keinginan menghukum diri, seperti keinginan untuk lari, bersembunyi dan bunuh diri. Simtom vegetatif menunjuk pada perubahan vegetatif, seperti gangguan makan, gangguan libido, dan gangguan tidur.

Nevid, Rathus, dan Greene (2005) juga menyebutkan bahwa pengalaman menjadi korban tindak kekerasan merupakan suatu pengalaman emosional yang sangat berpengaruh terhadap kesejahteraan psikologis korban. Analisis dengan menggunakan pendekatan psikodinamika menjelaskan bahwa depresi yang dialami oleh perempuan korban kekerasan terjadi akibat adanya emosi-emosi negatif, seperti marah, takut, dan malu yang dipendam oleh korban. Pelaku kekerasan yang pada umumnya merupakan orang yang dikenal dan juga dicintai menyebabkan korban terombangambing antara perasaan cinta sekaligus marah kepada pelaku kekerasan. Getzfeld (2004) dan Nevid dkk (2005) menyatakan bahwa perasaan ambivalen yang kuat merupakan kombinasi antara perasaan positif (cinta) dan perasaan negatif (marah atau permusuhan) yang akan menyebabkan seseorang mengarahkan emosi ke dalam dirinya. Perempuan korban kekerasan menjadi merasa marah pada diri sendiri, merasa malu atas pengalaman yang dialami, dan merasa bersalah karena tidak mampu melindungi diri sendiri. Hal ini pada akhirnya akan berujung pada terjadinya depresi. Gangguan depresi pada perempuan korban kekerasan merupakan gangguan yang serius dan perlu untuk ditangani segera karena gangguan ini dapat menyebabkan terhambatnya potensi korban untuk dapat berkembang dan bermanfaat bagi diri sendiri dan lingkungan.

Dalam beberapa penelitian terakhir, penanganan depresidengan menggunakan psikoterapi terutama melalui pendekatan kognitif terbukti efektif dalam mengurangi depresi. Walaupun demikian, McDonagh (Akbar, 2007) menyebutkan bahwa pendekatan kognitif dapat menimbulkan efek-efek yang bersifat persisten terhadap simptom stres traumatik. Banyak subjek yang mengalami drop out pada saat pelaksanaan terapi kognitif sehingga dinilai pendekatan kognitif ini perlu dikombinasikan dengan beberapa teknik intervensi lainnya, misalnya melalui pendekatan emosi.

Nevid dkk (2005) menjelaskan bahwa penanganan depresi dapat dilakukan dengan membantu subjek untuk menggali perasaan-perasaan yang selama ini dipendam dan kemudian mengekspresikannya ke luar dan bukan membiarkan menjadi lebih buruk dan mengarah ke dalam. Peneliti berpendapat bahwa hal ini sesuai untuk menangani depresi pada perempuan 
korban kekerasan yang lebih banyak menyimpan peristiwa kekerasan dan tidak berani mengkomunikasikannya karena dianggap aib serta tidak mengetahui cara menyalurkan emosi yang dirasakan.

Sebenarnya, penyaluran emosi dan penyingkapan dapat dilakukan dengan berbagai cara, salah satunya adalah dengan menulis. Menulis merupakan cara yang dapat digunakan seseorang untuk mengkomunikasikan berbagai emosi yang dirasakan. Pennebaker (1997) menjelaskan bahwa mekanisme proses terapeutik menulis pengalaman emosional berpusat pada penyingkapan (disclosure) pengalaman-pengalaman emosional. Pengakuan dan penyingkapan diri merupakan proses dasar yang muncul dalam psikoterapi dan secara alamiah muncul dalam interaksi sosial yang dianggap membawa manfaat secara psikologis.

Pennebaker (1997) juga menyebutkan bahwa menghadapi isu-isu pribadi secara mendalam melalui menulis ternyata menghasilkan kesehatan fisik, kesejahteraan subjektif, dan tingkah laku adaptif. Lebih lanjut Pennebaker (1997) menjelaskan mengenai kelebihan dari terapi menulis, yaitu tidak terikat pada usia tertentu, dapat diterapkan pada berbagai latar belakang budaya, bebas dari adanya umpan balik sosial (social feedback), serta dapat diterapkan pada berbagai kasus. Karakteristik menulis yang bebas dari umpan balik sosial (social feedback) ini dapat memotivasi seseorang untuk mau menyingkapkan hal-hal yang selama ini ditutupi.

Walaupun banyak memfokuskan pada emosi, namun menulis pengalaman emosional tidak semata-mata hanya merupakan suatu kerja emosi melainkan juga merupakan suatu aktivitas kognitif. Cameron dan Nicholls (1998) menjelaskan bahwa menulis dapat memfasilitasi penyesuaian terhadap peristiwa yang penuh dengan tekanan dengan mengintegrasikan keyakinan, emosi, dan pengalaman, sehingga individu dapat lebih baik memahami peristiwa dan mengidentifikasikan cara-cara untuk mengatasinya. Penelitian oleh Greenberg (1996) menyimpulkan bahwa menceritakan kembali suatu peristiwa dapat memberikan kesempatan pada kognisi untuk memproses dengan lebih baik. Dengan demikian menulis mengenai pengalaman emosional merupakan gabungan yang integratif antara pendekatan kognitif dan pendekatan emosi.

$$
\text { Balkie dan Wilhelm }
$$

(2005) merangkum berbagai penelitian yang menunjukkan bahwa menulis secara ekspresifmengenaipengalamanemosional akan memberikan manfaat jangka pendek maupun jangka panjang. Manfaat jangka pendek berkaitan dengan penurunan tingkat stres, sedangkan manfaat jangka panjang berkaitan perbaikan mood, merasakan kesejahteraan psikologis, dan perbaikan fungsi fisiologis secara umum. 
Berdasarkan uraian di atas, maka karena itu, peneliti membuat hipotesis dapat ditarik simpulan bahwa menulis penelitian bahwa intervensi menuliskan pengalaman emosional berpeluang pengalaman emosional yang pernah menjadi salah satu alternatif terapi mereka alami dapat menurunkan depresi bagi perempuan korban kekerasan perempuan korban kekerasan. Dinamika untuk mengurangi depresi. Oleh psikologisnya dapat dilihat dari bagan ini.

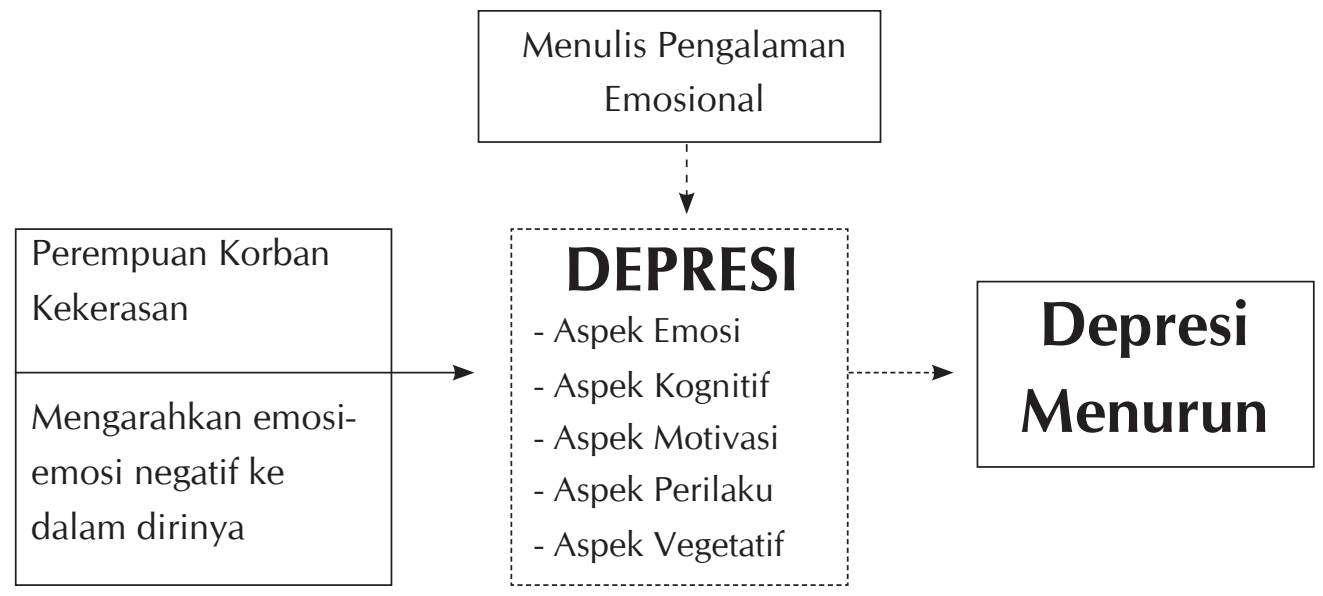

\section{Gambar 1. Kerangka berpikir penelitian}

\section{Keterangan:}

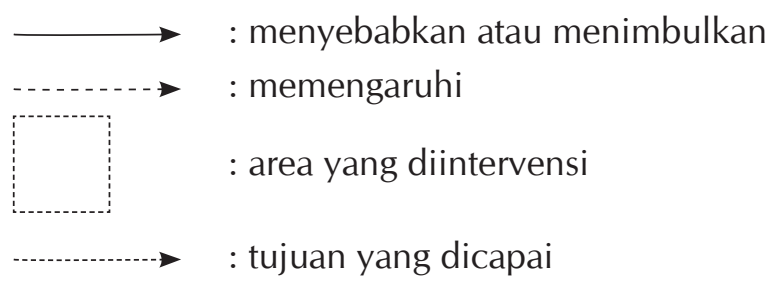

\section{METODE PENELITIAN}

\section{Subjek Penelitian}

Subjek penelitian ini adalah perempuan dewasa awal (19-39 tahun) yang dalam perjalanan hidupnya pernah menjadi korban kekerasan, baik kekerasan fisik maupun kekerasan psikologis, minimal mengalami depresi ringan (yang ditunjukkan dengan skor
BDI), dan bersedia untuk mengikuti sesi menulis pengalaman emosional selama 4 sesi. Subjek dipilih dari klien PSKW (Panti Sosial Karya Wanita) Sidoarum. Keterangan mengenai perjalanan hidup subjek diperoleh dari wawancara dengan pekerja sosial di PSKW sebagai pihak yang paling mengetahui latar belakang keberadaan subjek di panti tersebut. 


\section{Rancangan Penelitian}

Penelitian ini menggunakan between group design pretest posttest control group design, yaitu metode eksperimen yang berusaha untuk membandingkan suatu efek perlakuan terhadap variabel tergantung yang diuji dengan cara membandingkan keadaan variabel tergantung pada kelompok eksperimen setelah dikenai perlakuan dengan kelompok kontrol yang tidak diberi perlakuan (Azwar, 1998).

Tabel 1. Rancangan Eksperimen Pretest-Posttest Control Group Design

\begin{tabular}{llrll}
\hline KE & O1 & $X$ & O2 & O3 \\
KK & O1 & $\sim X$ & O2 & O3 \\
\hline
\end{tabular}

\section{Keterangan:}

KE : Kelompok Eksperimen

KK : Kelompok Kontrol

O1 : Pengukuran sebelum perlakuan (prates)

O2 : Pengukuran setelah perlakuan (pascates)

O3 : Pengukuran dua minggu setelah perlakuan (follow-up)

X $\quad$ : Perlakuan (prosedur menulis pengalaman emosional)

$\sim$ X : Tidak diberi perlakuan

\section{Pengukuran}

Pengumpulan data dalam penelitian ini dilakukan dengan menggunakan alat ukur BDI (Beck Depression Inventory), wawancara, dan observasi. BDI sendiri merupakan inventori untuk mengukur depresi individu. Adapun aspek-aspek depresi dalam penelitian ini mengacu pada aspek-aspek depresi menurut teori depresi Beck (1985), yaitu:

1. Aspek Emosional

Yaitu aspek afektif dari depresi yang meliputi kesedihan, berkurang kesenangan, apatis, hilangnya perasaan cinta terhadap orang lain, kecemasan, dan hillangnya respon terhadap kegembiraan.

2. Aspek Motivasional

Aspek motivasional mencakup adanya keinginan untuk menghindar dari permasalahan kehidupan seharihari dan harapan untuk melarikan diri dari kehidupan (biasanya ditandai dengan adanya keinginan untuk bunuh diri.

3. Aspek Kognitif

Aspek kognitif meliputi kesulitan untuk berkonsentrasi, perhatian yang sempit terhadap masalah, serta kesulitan mengingat. Selain itu 
terdapat pula distorsi kognitif yang meliputi pandangan negatif terhadap dirinya sendiri, dunia dan masa depannya, persepsi keputusasaan, hilangnya harga diri, rasa bersalah, dan penyiksaan terhadap diri.

4. Aspek Perilaku

Aspek perilakumerupakan refleksi dari aspek-aspek yang telah dijelaskan sebelumnya, meliputi kepasifan seperti tidur dalam waktu yang lama, menarik diri dari hubungan dengan orang lain, retardasi serta agitasi.

5. Aspek Vegetatif

Aspek fisik dan vegetatif dari depresi yang meliputi gangguan tidur, gangguan nafsu makan, serta gangguan aktivitas seksual.

Pengukuran tingkat depresi dilakukan dengan menggunakan Beck Depression Inventory (BDI). Pengukuran tingkat depresi dilakukan sebelum pelaksanaan prosedur menulis pengalaman emosional, setelah pelaksanaan prosedur, dan dua minggu setelah pelaksanaan prosedur.

Wawancara yang digunakan berbentuk wawancara semi terstruktur, dilakukan dua kali, yaitu sebelum dan setelah prosedur menulis pengalaman emosional selama 4 sesi berakhir. Sementara observasi yang digunakan adalah observasi eksperimental dan pencatatan observasi menggunakan anecdotal record.

\section{Prosedur Intervensi}

1. Lama Pelaksanaan Prosedur

Pelaksanaan prosedur menulis pengalaman emosional dilakukan dalam 4 sesi selama 2 minggu (perminggu 2 sesi) dengan lama waktu tiap sesi kurang lebih 30 menit. Apabila waktu sudah melampaui 30 menit namun subjek masih terus menulis, maka terapis akan membiarkan hingga subjek menghentikan sendiri kegiatan menulisnya. Selanjutnya terapis akan meminta subjek untuk memasukkan tulisannya dalam amplop yang telah disediakan.

2. Pengaturan Ruangan

Pelaksanaan prosedur dilakukan di suatu ruang kelas dengan meja tulis dan kursi bagi masing-masing subjek. Jarak antara masing-masing subjek diatur sedemikian rupa sehingga dapat memberikan privasi bagi tiap-tiap subjek dalam menuliskan pengalaman emosionalnya. Pelaksanaan dilakukan di ruang kelas dengan pencahayaan dan suhu yang mencukupi dan nyaman bagi subjek untuk melakukan proses menulis.

3. Alat Bantu

Alat bantu yang digunakan untuk masing-masing subjek adalah: (1) alat tulis berupa sebuah bolpoin, (2) kertas folio bergaris, (3) amplop coklat, dan (4) lem kertas. 
Tabel 2. Agenda Pelaksanaan Prosedur Menulis Pengalaman Emosional

\begin{tabular}{|c|c|c|c|c|}
\hline \multicolumn{2}{|c|}{ Pelaksanaan } & \multirow{2}{*}{\begin{tabular}{l}
\multicolumn{1}{c}{ Aktivitas } \\
Pembukaan \\
dan penjelasan \\
terapi
\end{tabular}} & \multirow[b]{2}{*}{$\begin{array}{l}\text { Tujuan } \\
\text { Membangun rapport antara terapis dan } \\
\text { klien, memberikan penjelasan pada } \\
\text { klien mengenai terapi yang akan di- } \\
\text { jalani, memotivasi klien untuk terus } \\
\text { mengikuti prosedur hingga sesi terakhir }\end{array}$} & \multirow{2}{*}{$\frac{\text { Waktu }}{13.15 \text { s.d } 13.30}$} \\
\hline Pertemuan 1 & 1.1 & & & \\
\hline & 1.2 & Sesi menulis & $\begin{array}{l}\text { Memberikan instruksi pada klien untuk } \\
\text { menceritakan pengalaman emosional- } \\
\text { nya dalam bentuk tulisan. }\end{array}$ & 13.30 s.d 14.00 \\
\hline & 1.3 & Penutup & $\begin{array}{l}\text { Menutup sesi pertama dan memotivasi } \\
\text { agar klien hadir lagi pada sesi berikut- } \\
\text { nya }\end{array}$ & 14.00 s.d. 14.10 \\
\hline \multirow[t]{3}{*}{ Pertemuan 2} & 2.1 & Pembukaan & $\begin{array}{l}\text { Memotivasi klien agar lebih ekspresif } \\
\text { dan terbuka dalam menulis }\end{array}$ & 13.00 s.d 13.10 \\
\hline & 2.2 & Sesi menulis & $\begin{array}{l}\text { Memberikan instruksi pada klien untuk } \\
\text { menceritakan pengalaman emosional- } \\
\text { nya dalam bentuk tulisan }\end{array}$ & 13.10 s.d 13.40 \\
\hline & 2.3 & Penutup & $\begin{array}{l}\text { Menutup sesi kedua dan memotivasi } \\
\text { agar klien hadir lagi pada sesi berikut- } \\
\text { nya }\end{array}$ & 13.40 s.d 14.00 \\
\hline \multirow[t]{3}{*}{ Pertemuan 3} & 3.1 & Pembukaan & $\begin{array}{l}\text { Memotivasi klien agar lebih ekspresif } \\
\text { dan terbuka dalam menulis }\end{array}$ & 13.10 s.d 13.20 \\
\hline & 3.2 & Sesi menulis & $\begin{array}{l}\text { Memberikan instruksi pada klien untuk } \\
\text { menceritakan pengalaman emosional- } \\
\text { nya dalam bentuk tulisan }\end{array}$ & 13.20 s.d 13.50 \\
\hline & 3.3 & Penutup & $\begin{array}{l}\text { Menutup sesi ketiga dan memotivasi } \\
\text { agar klien hadir lagi pada sesi berikut- } \\
\text { nya }\end{array}$ & 13.50 s.d. 14.00 \\
\hline \multirow[t]{3}{*}{ Pertemuan 4} & 4.1 & Pembukaan & $\begin{array}{l}\text { Memotivasi klien agar lebih ekspresif } \\
\text { dan terbuka dalam menulis }\end{array}$ & 13.00 s.d 13.10 \\
\hline & 4.2 & Sesi menulis & $\begin{array}{l}\text { Memberikan instruksi pada klien untuk } \\
\text { menceritakan pengalaman emosional- } \\
\text { nya dalam bentuk tulisan }\end{array}$ & 13.10 s.d. 13.40 \\
\hline & 4.3 & $\begin{array}{l}\text { Penutup dan } \\
\text { terminasi terapi }\end{array}$ & $\begin{array}{l}\text { Terminasi terapi dan memotivasi klien } \\
\text { untuk meneruskan kebiasaan menceri- } \\
\text { takan pengalaman emosionalnya dalam } \\
\text { bentuk tulisan }\end{array}$ & 13.40 s.d 13.20 \\
\hline
\end{tabular}


Tabel 3. Deskripsi Data Penelitian

\begin{tabular}{|c|c|c|c|c|c|c|}
\hline \multirow{3}{*}{ Kelompok } & \multicolumn{3}{|c|}{ Pengukuran } & \multicolumn{3}{|c|}{ Selisih skor BDI } \\
\hline & \multirow{2}{*}{ Prates } & \multirow{2}{*}{ Pascates } & \multirow{2}{*}{ Follow-up } & \multirow{2}{*}{$\begin{array}{c}\text { G1 } \\
\text { Pratest- } \\
\text { Pascates }\end{array}$} & \multirow{2}{*}{$\begin{array}{c}\text { G2 } \\
\text { Pascates- } \\
\text { follow-up }\end{array}$} & \multirow{2}{*}{$\begin{array}{c}\text { G3 } \\
\text { Pra test- } \\
\text { follow-up }\end{array}$} \\
\hline & & & & & & \\
\hline \multicolumn{7}{|l|}{ Eksperimen } \\
\hline 1 & 16 & 14 & 13 & -2 & -1 & -3 \\
\hline 2 & 19 & 5 & 5 & -14 & 0 & -14 \\
\hline 3 & 10 & 6 & 9 & -4 & 3 & -1 \\
\hline 4 & 26 & 23 & 17 & -9 & -6 & -8 \\
\hline 5 & 18 & 4 & 0 & -14 & -4 & -18 \\
\hline 6 & 17 & 0 & 2 & -17 & 2 & -15 \\
\hline 7 & 25 & 9 & 17 & -16 & 8 & -8 \\
\hline Mean & 18,71 & 8,71 & 9,0 & $-10,85$ & 0,28 & $-9,57$ \\
\hline \multicolumn{7}{|l|}{ Kontrol } \\
\hline 1 & 11 & 19 & 13 & 8 & -6 & 2 \\
\hline 2 & 17 & 17 & 7 & 0 & -10 & -10 \\
\hline 3 & 22 & 21 & 27 & -1 & 7 & 5 \\
\hline 4 & 29 & 28 & 29 & -1 & 1 & 0 \\
\hline 5 & 16 & 22 & 18 & 6 & -4 & 2 \\
\hline 6 & 23 & 16 & 16 & -7 & 0 & -7 \\
\hline 7 & 18 & 12 & 5 & -6 & -7 & -13 \\
\hline Mean & 19,43 & 19,29 & 16,43 & $-0,14$ & $-2,71$ & -3 \\
\hline
\end{tabular}

Tabel 4. Statistik Deskriptif

\begin{tabular}{lccccc}
\hline & N & Minimum & Maximum & Mean & Std. Deviation \\
\hline BDI Prates Eksperimen & 7 & 10 & 26 & 18.71 & 5.469 \\
BDI Prates Kontrol & 7 & 11 & 29 & 19.43 & 5.798 \\
BDI Pascates Eksperimen & 7 & 0 & 23 & 8.71 & 7.653 \\
BDI Pascates Kontrol & 7 & 12 & 28 & 19.29 & 5.090 \\
BDI Follow-up Eksperimen & 7 & 0 & 17 & 9.00 & 6.952 \\
BDI Follow-up Kontrol & 7 & 5 & 29 & 16.43 & 9.163 \\
Valid N (listwise) & 7 & & & & \\
\hline
\end{tabular}




\section{Teknik Analisis data}

Analisis data dalam penelitian ini menggunakan teknik analisis statistik non parametrik dengan teknik analisis Wilcoxon dan U Mann Withney.

\section{HASIL PENELITIAN}

\section{Hasil Analisis Kuantitatif}

Data yang diperoleh dalam penelitian ini adalah tingkat depresi subjek pada kelompok eksperimen dan kelompok kontrol berdasarkan skor BDI yang diperoleh sebelum intervensi, setelah diberikan intervensi dan dua minggu sesudahnya.
Berdasarkan tabel 3, maka dapat diketahui deskripsi data seperti yang tertera pada tabel 4 :

Pengukuran setelah perlakuan (pascates) dan dua minggu setelah perlakuan (follow-up) pada kelompok eksperimen menunjukkan adanya penurunan rerata skor $\mathrm{BDI}$, sedangkan pengukuran setelah perlakuan (pascates) pada kelompok kontrol tidak menunjukkan adanya penurunan rerata skor BDI. Pada pengukuran dua minggu setelah perlakuan (follow-up) pada kelompok kontrol terdapat penurunan rerata skor BDI.

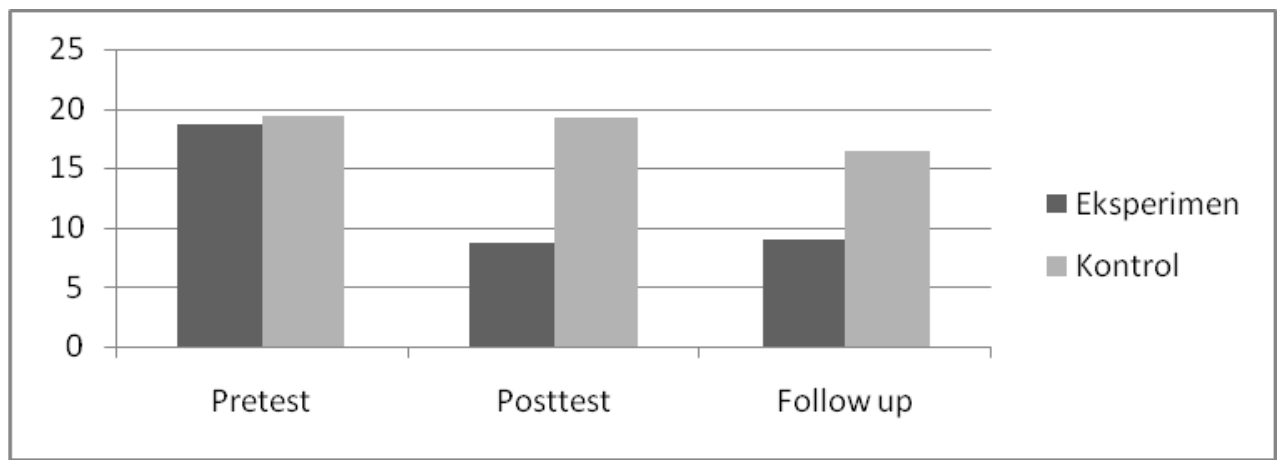

Gambar 2. Grafik Rerata Skor BDI Kelompok Eksperimen dan Kontrol

Uji Mann-Whitney dilakukan (prates ke pascates) yang signifikan antara untuk mengetahui perubahan tingkat kelompok eksperimen dengan kelompok depresi pada kelompok eksperimen dan kontrol. Hasil analisis juga menunjukkan kelompok kontrol dilakukan dengan bahwa tidak ada perbedaan perubahan menghitung gain score (selisih skor skor BDI (pascates ke follow-up) yang depresi). Hasil analisis menunjukkan signifikan antara kelompok eksperimen adanya perbedaan perubahan skor BDI dan kelompok kontrol (lihat tabel 5). 
Tabel 5. Hasil Uji Mann Whitney

\begin{tabular}{lccl}
\hline $\begin{array}{c}\text { Perhitungan } \\
\begin{array}{c}\text { (Kelompok kontrol - } \\
\text { kelompok eksperimen) }\end{array}\end{array}$ & Z & $\begin{array}{c}\text { Signifikansi } \\
(\mathrm{p})\end{array}$ & \multicolumn{1}{c}{ Keputusan } \\
\hline G1 (Prates - pascates) & $-2,625$ & 0,007 & Perbedaan signifikan \\
G2 (Pascates - Follow-up) & $-1,154$ & 0,259 & Perbedaan tidak signifikan \\
G3 (Prates - Follow-up) & $-1,857$ & 0,073 & Perbedaan tidak signifikan \\
\hline
\end{tabular}

Hasil uji Wilcoxon dilakukan untuk melihat perubahan skor BDI pada kelompok eksperimen. Dzdvnkiketahui $\mathrm{z}=2,371, \mathrm{p}<0,05$ yang menunjukkan bahwa terjadi perubahan skor BDI yang signifikan antara sebelum dilakukan prosedur menulis pengalaman emosional (prates) dengan sesudah dilakukan prosedur menulis pengalaman emosional (pascates). Namun skor BDI pascates dengan skor BDI yang diambil dua minggu setelah perlakuan tidak menunjukkan perbedaan yang signifikan.

Tabel 6. Hasil Uji Wilcoxon

\begin{tabular}{lrcl}
\hline $\begin{array}{c}\text { Perhitungan } \\
\text { (kel eksperimen) }\end{array}$ & $\mathrm{Z}$ & \multicolumn{2}{c}{ Signifikansi } \\
\\
\hline Prates ke pascates & $-2,371$ & 0,018 & \multicolumn{1}{c}{ Keputusan } \\
Pascatest ke follow-up & 0,105 & 0,917 & Perbedaan signifikan \\
\hline
\end{tabular}

Berdasarkan uraian di atas, maka diambil beberapa simpulan sebagai berikut:

1. Pada kelompok eksperimen dan kelompok kontrol terdapat perbedaan perubahan skor BDI yang sangat signifikan antara sebelum dan sesudah mengikuti prosedur menulis pengalaman emosional.

2. Pada kelompok eksperimen terdapat penurunan skor BDI yang signifikan antara sebelum dan sesudah mengikuti prosedur menulis pengalaman emosional.
3. Pada kelompok eksperimen tidak terdapat penurunan skor BDI yang signifikan antara sesudah mengikuti prosedur menulis pengalaman emosional dengan dua minggu setelahnya.

4. Pada kelompok eksperimen dan kelompok kontrol tidak terdapat perbedaan perubahan skor BDI yang signifikan antara sesudah mengikuti prosedur menulis pengalaman emosional dan dua minggu setelahnya. 


\section{Hasil Analisis Kualitatif}

Dari hasil analisis kualitatif per individu, maka diambil beberapa simpulan sebagai berikut:

1. Semua subjek mengalami penurunan tingkat depresi yang ditandai dengan penurunan grafik skor depresi serta penurunan kategori dari yang berat menjadi sedang, sedang menjadi ringan, atau dari yang ringan menjadi normal dan juga sedang menjadi normal.

2. Semua subjek mengaku mengalami perubahan lebih baik secara emosi yang ditandai dengan adanya perasaan senang, tenang, lega, dan ringan setiap kali selesai sesi menulis. Beberapa subjek menyatakan munculnya perasaan optimis pada dirinya dalam menghadapi masa depan dan dalam menghadapi masalah yang tengah dihadapinya.

3. Beberapa subjek menyatakan mengalami perubahan secara kognitif yang dinyatakan dengan pikiran yang lebih jernih, lebih fokus, serta menjadi lebih mampu untuk mengambil pelajaran dari pengalaman yang telah lalu.

4. Beberapa subjek mengaku mengalami kualitas tidur yang lebih baik setelah menjalani sesi menulis.

5. Mereka yang mengalami penurunaan skor depresi paling banyak adalah subjek yang pada saat menjalani sesi menulis terlihat paling serius dan bersungguh-sungguh sehingga dapat diasumsikan bahwa intensitas katarsis yang mereka lakukan pada saat menulis cukup tinggi.

\section{PEMBAHASAN}

Penelitian ini membuktikan adanya pengaruh menulis pengalaman emosional terhadap tingkat depresi pada perempuan korban kekerasan. Hipotesis penelitian dibuktikan dengan analisis statistik MannWhitney $U$, gain score (selisih nilai dari prates ke pascates) kelompok eksperimen dan kelompok kontrol yang menghasilkan nilai $z=2,625$ dan $p=0,007(p<0,05)$. Kondisi ini menunjukkan bahwa rerata perubahan perubahan nilai prates ke pascates kelompok eksperimen lebih besar daripada rerata perubahan nilai prates ke pascates pada kelompok kontrol. Dengan demikian dapat diambil simpulan bahwa terdapat perbedaan tingkat depresi yang signifikan antara kelompok yang memperoleh tritmen berupa menulis pengalaman emosional dengan kelompok yang tidak memperoleh tritmen.

Hasil uji Wilcoxon dilakukan untuk melihat perubahan skor BDI pada kelompok eksperimen, diketahui bahwa $\mathrm{z}=2,625, \mathrm{p}<0,01$ yang menunjukkan bahwa terjadi perubahan skor BDI yang signifikan antara sebelum dilakukan prosedur menulis pengalaman emosional (prates) dengan sesudah dilakukan prosedur menulis pengalaman emosional (pascates). Dengan demikian dapat diambil simpulan bahwa terjadi 
penurunan tingkat depresi yang signifikan antara sebelum melakukan intervensi menulis pengalaman emosional dan sesudah melakukan tritmen menulis pengalaman emosional.

Hasil ini sejalan dengan penelitian Crespo dan Arinero (2010) terhadap perempuan korban kekerasan. Mereka memberikan sejumlah rangkaian terapi psikologis di mana pada satu kelompok diberikan exposure untuk mengekspresikan rasa marah sedangkan kelompok lain diberikan teknik keterampilan berkomunikasi untuk mengekspresikan rasa marahnya. Hasilnya menunjukkan bahwa efektivitas terapi pada kelompok yang diberikan exposure terhadap ekspresi rasa marah lebih tinggi daripada kelompok yang diberikan teknik keterampilan berkomunikasi untuk dapat mengekspresikan rasa marahnya. Hal ini menunjukkan bahwa exposure (pengungkapan) dan ekspresi penting untuk mengatasi permasalahan psikologis yang dialami oleh perempuan korban kekerasan. Pengungkapan dan ekspresi ini merupakan bagian dari proses katarsis yang terjadi pada tritmen menulis pengalaman emosional yang dilakukan pada penelitian ini.

Hawkins (1995) menyebutkan bahwa pada model terapi yang berorientasi pada katarsis, seperti yang dilakukan pada tritmen menulis pengalaman emosional, berasumsi bahwa katarsis memiliki daya ubah yang sedemikian dramatis sehingga secara otomatis akan dapat mengubah kepribadian atau mengubah proses regulasi diri seseorang yang menyertai perubahan kepribadiannya. Model ini berpandangan bahwa begitu pengalaman katarsis tercapai, maka terjadi suatu proses otomatis yang mengubah seseorang menjadi lebih baik. Pendekatan ini menyebabkan katarsis dapat diterapkan pada hampir semua pasien dengan diagnosis apapun, termasuk untuk diagnosis depresi yang terjadi pada perempuan korban kekerasan.

Getzfeld (2004) menyebutkan bahwa menurut Freud dan para pengikutnya, depresi terjadi karena adanya emosi marah yang diarahkan ke dalam dan bukan kepada individu yang menyebabkan munculnya kemarahan itu. Seperti yang telah dijelaskan pada bab terdahulu, depresi yang dialami oleh perempuan korban kekerasan terjadi akibat adanya emosi-emosi negatif, seperti marah, takut, dan malu yang diarahkan pada dirinya sendiri oleh korban. Pelaku kekerasan, yang pada umumnya merupakan orang yang dikenal dan juga dicintai, menyebabkan korban terombang-ambing antara perasaan cinta sekaligus marah kepada pelaku kekerasan. Getzfeld (2004) dan Nevid dkk (2005) menyatakan bahwa perasaan ambivalen yang kuat yang merupakan kombinasi antara perasaan positif (cinta) dan perasaan negatif (marah atau permusuhan) akan menyebabkan seseorang mengarahkan emosi tersebut ke dalam dirinya. Emosi negatif yang 
diarahkan pada dirinya sendiri inilah yang pada akhirnya berujung pada terjadinya depresi.

Katarsis yang terjadi pada tritmen menulis pengalaman emosional memungkinkan bagi subjek untuk melepaskan emosi negatif yang selama ini dipendam. Tritmen menulis pengalaman emosional memberikan peluang pada subjek untuk mengekspresikan keluar emosi negatif, seperti rasa marah, sedih, dan malu, tanpa khawatir mendapatkan respon negatif dari lingkungan sekitar. Dengan mengungkapkan dan mengekspresikan emosi-emosi negatif yang terpendam, maka terjadi pelepasan ketegangan sehingga banyak di antara subjek yang menyatakan dirinya merasa lega dan mengalami perasaan lebih baik daripada sebelum melakukan tritmen menulis pengalaman emosional. Hal inilah yang menjelaskan mengapa katarsis yang terjadi pada tritmen menulis pengalaman emosional dapat menurunkan tingkat depresi pada subjek yang berada di kelompok eksperimen.

Dari hasil wawancara yang dilakukan setelah tritmen menulis pengalaman emosional berakhir terlihat bahwa subjek yang berada di kelompok eksperimen mengalami kelegaan emosional setiap selesai sesi menulis. Hal ini dinyatakan dengan berbagai ungkapan mereka, seperti merasa lebih lega, lebih ringan, merasa puas karena sudah menumpahkan 'unek-unek', dan sebagainya. Hasil ini menunjukkan menulis pengalaman emosional berpengaruh pada aspek afektif dari depresi yang dialami perempuan korban kekerasan. Dengan mengungkapkan dan mengekspresikan emosi negatif seperti emosi marah, sedih dan malu yang dialaminya dalam bentuk tulisan, maka pendaman emosi negatif itu kemudian berkurang sehingga subjek merasa lebih ringan dan lebih lega.

Dari hasil wawancara juga disebutkan bahwa setelah melakukan tritmen menulis pengalaman emosional, beberapa subjek merasa lebih semangat dalam mengikuti kegiatan di panti. Selain itu juga ada subjek yang mengaku menjadi lebih optimis dalam menghadapi permasalahan hidupnya walaupun belum tahu solusi dari permasalahan yang dihadapinya, serta ada subjek yang menyatakan lebih yakin akan masa depannya. Hal ini menunjukkan bahwa tritmen menulis pengalaman emosional berpengaruh pada aspek motivasional dari depresi yang dialami perempuan korban kekerasan. Pengaruh ini dapat dijelaskan bahwa dengan terjadinya pelepasan emosi negatif yang menyebabkan munculnya perasaan lega, ringan, dan merasa lebih baik pada perempuan korban kekerasan pada akhirnya bermuara pada munculnya semangat dalam menjalani kegiatan seharihari dan optimisme dalam menghadapi permasalahan dalam hidupnya. Hal ini sejalan dengan penelitian Rowan dan Reason (Hawkins, 1995) bahwa setelah 
melakukan katarsis, maka seseorang itu akan memiliki perasaan yang baik, merasa mudah untuk menghadapi apa yang tengah dijalani, dan merasa mampu untuk mencapai apa yang ingin dicapai.

Beberapa subjek yang juga menyatakan perubahan pada dirinya yang terwujud dalam bentuk lebih konsentrasi dalam menerima pelajaran di panti dan merasa bahwa pikirannya sudah lebih ringan dan 'tidak sumpek' lagi. Hal ini menunjukkan bahwa tritmen menulis pengalaman emosional berpengaruh pada aspek kognisi dalam depresi pada perempuan korban kekerasan. Hal ini sejalan dengan pernyataan Greenberg (1996) yang menyebutkan bahwa kerja kognitif biasanya terganggu saat peristiwa emosional terjadi sehingga pengalamanpengalaman sekitar peristiwa emosional tersebut terproses dengan baik ke dalam struktur kognitif. Menceritakan kembali dengan cara menulis dapat memberikan kesempatan pada kognisi untuk memproses dengan lebih baik. Tritmen menulis pengalaman emosional ini juga memberikan kesempatan pada subjek untuk menemukan pemaknaan baru (insight) terhadap hal-hal yang terjadi saat ini yang dipengaruhi oleh pengalaman masa lampaunya. Hal-hal ini kemudian menyebabkan proses kognitif pada perempuan korban kekerasan menjadi lebih baik sehingga mampu untuk lebih konsentrasi dan lebih tenang dalam berfikir.
Perubahan aspek perilaku dari depresi yang dialami perempuan korban kekerasan terlihat dari pengakuan subjek yang menyatakan bahwa saat ini dirinya lebih mudah untuk bergaul dan menanggapi teman-temannya dengan bercanda. Perubahan juga dapat dilihat pengakuan subjek yang merasa lebih semangat dalam mengikuti kegiatan di panti. Dengan demikian perilaku menarik diri dari lingkungan sosial tampaknya cukup dipengaruhi oleh tritmen menulis pengalaman emosional walaupun ada subjek yang mengaku tetap merasa lebih senang menyendiri dibandingkan bergaul dengan teman-teman lainnya.

Subjek pada kelompok eksperimen juga menyatakan bahwa terdapat perubahan dalam hal nafsu makan dan pola tidur di mana terdapat subjek yang mengaku lebih 'enak makan' serta mengalami tidur yang lebih lelap setiap selesai sesi menulis pengalaman emosional. Perubahan ini menunjukkan pengaruh tritmen menulis pengalaman emosional pada aspek vegetatif dari depresi yang dialami oleh perempuan korban kekerasan.

Walaupun demikian, hasil analisis kuantitatif dengan menggunakan uji Mann Whitney menunjukkan bahwa tidak ada perbedaan perubahan skor BDI (pascates ke follow-up) yang signifikan antara kelompok eksperimen dan kelompok kontrol. Dengan demikian dapat diambil simpulan bahwa pada 
pengukuran dua minggu setelah tritmen menulis pengalaman emosional, tidak ada perbedaan perubahan tingkat depresi antara kelompok eksperimen dan kelompok kontrol. Begitu pula hasil uji Wilcoxon dilakukan untuk melihat perubahan skor BDI pada kelompok eksperimen, skor $\mathrm{BDI}$ pascates dengan skor BDI yang diambil dua minggu setelah perlakuan tidak menunjukan perbedaan yang signifikan ( $z=0,105$, $p>0,05)$. Dari hasil ini dapat diambil simpulan bahwa efek dari tritmen menulis pengalaman emosional ternyata tidak bertahan hingga dua minggu setelah tritmen tersebut diberikan.

Dari analisis kuantitatif yang ditunjukkan dari grafik skor BDI yang dialami subjek juga terlihat bahwa pada subjek 1, 4 dan 5, skor BDI mengalami penurunan dari pengukuran pascates ke pengukuran follow-up. Subjek 2 tidak mengalami penurunan skor BDI antara pengukuran pascates dan pengukuran follow-up, sedangkan subjek 3, 6 dan 7 justru mengalami kenaikan skor BDI pada saat pengukuran follow-up dibandingkan saat pengukuran pascates.

Dari hasil analisis kuantitatif diketahui bahwa subjek 2, subjek 5 dan subjek 7 adalah mereka yang mengalami penurunan skor BDI yang cukup banyak pada pengukuran pascates apabila dibandingkan dengan pengukuran sebelum dilakukan tritmen. Apabila dikaitkan dengan data hasil observasi, maka mereka ini adalah subjek yang cukup serius dalam melakukan tritmen menulis pengalaman emosional yang ditandai dengan perilaku menulis terus menerus, tidak mudah teralihkan perhatiannya, perubahan ekspresi wajah pada saat sesi menulis yang menunjukkan besarnya aspek emosi yang terlibat pada saat mereka menulis, serta tergolong yang selesai terakhir dalam menulis yang dapat diasumsikan bahwa intensitas katarsis mereka dalam menulis cukup tinggi.

Dari hasil analisis kuantitatif per subjek juga terlihat bahwa subjek 3, subjek 6 dan subjek 7 mengalami kenaikan skor BDI antara sesudah pemberian perlakuan (pascates) dengan dua minggu sesudahnya (follow-up). Walaupun demikian pada subjek 3 dan 6 kenaikan skor itu tidak menunjukkan kenaikan kategori tingkat depresi karena masih berada pada kategori yang sama yaitu normal. Hanya pada subjek 7 terjadi kenaikan kategori tingkat depresi yaitu dari normal (skor 9) menjadi depresi sedang (skor 17). Dari data kualitatif diketahui bahwa subjek 7 mengalami kekerasan psikis dari pacarnya sehingga mengalami kehamilan yang tidak diinginkan dan harus menjadi orangtua tunggal pada usia yang masih belia. Hal ini menunjukkan bahwa tingkat keparahan kekerasan yang dialaminya cukup dalam sehingga subjek 7 lebih mudah untuk mengalami depresi.

Dari hasil tulisan subjek di kelompok eksperimen terlihat bahwa pada umumnya 
subjek belum banyak menggunakan katakata berupa ekspresi emosi, seperti kata marah, sedih, kecewa dan sebagainya, walaupun hal tersebut sudah dijelaskan pada lembar instruksi. Begitu pula dari isi tulisan yang diungkapkan oleh subjek, belum merupakan tulisan yang berisi pengalaman emosional subjek yang terkait dengan peristiwa kekerasan yang pernah dialaminya.

Terdapat beberapa kelemahan terdapat dalam penelitian ini. Salah satunya adalah bahwa penelitian ini juga tidak mengendalikan faktor-faktor yang memengaruhi depresi pada perempuan korban kekerasan seperti tingkat keparahan yang terjadi, dukungan sosial dan pengalaman kekerasan seksual di masa kanak-kanak. Pemilihan subjek lebih banyak didasarkan atas hasil wawancara dengan pekerja sosial yang ada di panti yang diasumsikan mengetahui persis mengenai kondisi dan latar belakang perempuan korban kekerasan yang manjadi penghuni panti tersebut.

Selain itu penelitian ini juga tidak mengendalikan seberapa lama subjek sudah menjadi penghuni panti. Tidak dilakukannya pengendalian adalah karena dasar pertimbangan jumlah subjek yang tidak terlau banyak serta bahwa tingkat mobilitas perempuan korban kekerasan yang tinggal di panti tersebut cukup tinggi. Hal ini terkait dengan latar belakang permasalahan yang unik pada tiap-tiap subjek.
Kekurangan dari modul prosedur menulis pengalaman emosional yang digunakan pada penelitian ini adalah pada instruksi topik menulis di tiap sesi yang hampir serupa dan kurang spesifik sehingga tidak memunculkan topik yang sebenarnya diharapkan untuk muncul. Apabila topik di tiap sesi dinyatakan secara lebih jelas dan spesifik seperti misalnya: 'tuliskan pengalaman yang paling menyakitkan yang pernah dilakukan lakilaki pada anda', maka dimungkinkan akan muncul tulisan-tulisan yang berhubungan dengan emosi negatif yang selama ini mereka pendam dalam diri mereka. Selain itu modul ini juga kurang menekankan subjek untuk meneruskan kegiatan menulis pengalaman emosional hingga menjadi suatu kebiasaan yang terinternalisasi dalam kehidupan mereka sehari-hari.

\section{SIMPULAN DAN SARAN}

\section{Simpulan}

Berdasarkan hasil analisis kuantitatif dan kualitatif pada penelitian ini dapat disimpulkan bahwa hipotesis penelitian yang menyebutkan menulis pengalaman emosional dapat menurunkan tingkat depresi pada perempuan korban kekerasan terbukti diterima. Penurunan tingkat depresi pada perempuan korban kekerasan terjadi pada saat setelah dilakukannya prosedur menulis pengalaman emosional, namun penurunan tingkat depresi tidak terjadi pada jangka 
waktu dua minggu setelahnya. Dengan demikian prosedur menulis pengalaman emosional ini dapat digunakan sebagai awalan atau pembuka dan perlu untuk dikombinasikan dengan serangkaian intervensi lainnya yang ditujukan untuk menurunkan depresi pada perempuan korban kekerasan.

\section{Saran}

1. Untuk peneliti selanjutnya

Disarankan melakukan pengendalian terhadap faktor-faktor yang tidak dikendalikan dalam pemilihan subjek penelitian ini, seperti tingkat keparahan yang terjadi dan lama tinggal di panti. Selain itu juga disarankan untuk melakukan penelitian di komunitas dan bukan di panti seperti yang ada di penelitian ini, sehingga dapat memperluas dan memperkaya khazanah penelitian mengenai perempuan korban kekerasan.

2. Untuk pengelola panti dan pihak terkait

Diharapkan untuk dapat mempelajari terapi menulis sebagai salah satu tritmen yang diberikan pada perempuan korban kekerasan, baik diberikan secara klasikal maupun secara individual. Sangat disarankan untuk memberikan buku harian pada tiap penghuni panti sehingga mereka memiliki media untuk menuliskan perasaan dan pikirannya.

3. Untuk subjek penelitian

Disarankan untuk membiasakan diri mengungkapkan perasaan dan pikiran dalam bentuk tulisan, sehingga dapat menjadi salah satu cara dalam memperoleh perasaan yang lebih baik serta pikiran yang lebih jernih ketika menghadapi permasalahan kehidupan.

\section{DAFTAR PUSTAKA}

Akbar, Z. (2007). Efektivitas Pelatihan Manajemen Emosi sebagai Program Pemulihan untuk Mengatasi Depresi pada Remaja Korban Gempa Bumi. Tesis. (tidak diterbitkan). Yogyakarta: PPS UGM.

Azwar, S. (1998). Metode Penelitian. Yogyakarta: Pustaka Pelajar.

Beck, AT. (1985). Depression: Causes and Treatment. Philadelphia: University of Pennsylvania.

Cameron, L.D. \& Nicholls, G. (1998). Expression of Stressful Experiences Through Writing: Effects of a Self regulation Manipulation for Pessimist and Optimist. Health Psychology, 17 (1), 84-92. 
Crespo, M \& Arinero, M. (2010). Assesment of the Efficacy of a Psychological Treatment for Women Victims of Violence by Their Intimate Male Patner. The Spanish Journal of Psyhology, 13 (2), 849-863.

Darmawan, D.A. (2005). Kekerasan terhadap Istri (Analisis mengenai jenis kekerasan dan perkembangan terakhir klien Rifka Annisa WCC tahun 2002-2003). Tesis. (tidak diterbitkan). Yogyakarta : PPS UGM.

Getzfeld, A.R. (2004). Abnormal Psychology Casebook. A New Perspektif. New Jersey: Prentice Hall.

Greenberg, M.A., Wortman, C.B. \& Stone, A.A. (1996). Emotional Expression and Physical Health. Revising Traumatic Memories of Fostering Self Regulation. Journal of Personality and Social Psychology, 71 (3), 588-602.

Hawkins, P.J. (1995). Catharsis in Counselling Psychology. Health Psychology. United Kingdom: School of Health Studies University of Sunderland.
Mandatu, A. (2009). Kekerasan Terhadap Pasangan Dalam Rumah Tangga. (http ://psikologi-online.com diakses pada 21 Maret 2009.

Nevid, J.S., Rathus, S.A, \& Greene, B. (2005). Psikologi Abnormal. Edisi kelima. Jakarta: Penerbit Erlangga.

Pennebaker, J.W. (1997). Writing about Emotional Experience as a Therapeutic Process. Psychological Science, 8 (3), 162-166.

Uyun, Q. (2004). Pelatihan Asertivitas untuk Meningkatkan Ketahanan Istri Terhadap Tindak Kekerasan Suami. Tesis. (tidak diterbitkan). Yogyakarta: PPS UGM.

Wardhani, Y.F. \& Lestari, W. (2007). Gangguan Stres Pasca Trauma pada korban Pelecehan Seksual dan Perkosaan. Surabaya: Pusat Penelitian dan Pengembangan Sistim dan Kebijakan Kesehatan.

Zubaidah, S. (2001). Tafsir Ulang terhadap Hadist-hadist tentang Kekerasan terhadap Istri. Laporan Penelitian (tidak diterbitkan). Yogyakarta: PSW UII. 